\title{
A Sustainable Comprehensive Service through Greater Involvement of People Living with HIV/AIDS in the HIV/AIDS Management Program in Surakarta City of Indonesia
}

\author{
Argyo Demartoto ${ }^{1}$, Endang Gerilyawati IES ${ }^{2} \&$ Desiderius Priyo Sudibyo ${ }^{3}$ \\ ${ }^{1}$ Department of Sociology, Faculty of Social and Political Sciences, Sebelas Maret University, Surakarta, \\ Indonesia \\ ${ }^{2}$ Study Program of Physician Education, Faculty of Medical, Sebelas Maret University, Surakarta, Indonesia \\ ${ }^{3}$ Department of Administration Science, Faculty of Social and Political Sciences, University Sebelas Maret, \\ Surakarta, Indonesia \\ Correspondence: Argyo Demartoto, Department of Sociology, Faculty of Social and Political Sciences, Sebelas \\ Maret University, Ir. Sutami Street 36 A Kentingan, Surakarta 57121, Indonesia. Tel: 62-271-637-277. E-mail: \\ argyodemartoto@ymail.com
}

Received: October 19, 2013 Accepted: December 2, 2013 Online Published: January 26, 2014

doi:10.5539/ass.v10n4p52

URL: http://dx.doi.org/10.5539/ass.v10n4p52

\begin{abstract}
This research aimed to find out the demographic, social and economic characteristics of people living with HIV/AIDS (PLWHA); stakeholders' knowledge, attitude, and behavior toward HIV/AIDS and people with HIV/AIDS; comprehensive and sustainable support and service, the application of Greater Involvement of People With HIV/AIDS (GIPA) as well as the contribution of stakeholders to the HIV/AIDS management program in Surakarta City. The research method employed was an exploratory one. The sampling technique used was purposive sampling one. The data collection was conducted using observation, in-depth interview, Focus Group Discussion, and documentation. Technique of analyzing data used was an interactive model of analysis. The result of research showed that in Surakarta, generally PLWHA were productive, male, heterosexual and working as employees, having medical problem and social culture such as developing opportunistic infection, antriretroviral (ARV) drug side effect, depression, experiencing discrimination, negative stigma, isolation by the family and society member. The stakeholders of sustainable and comprehensive service in dealing with HIV/AIDS in Surakarta City had good knowledge about HIV/AIDS, caring and responsiveness to the PLWHA. A comprehensive and sustainable support and service started during undertaking test; ARV drugs procurement, ethical and non-discriminatory treatment; opportunistic infection prevention and treatment; non-medical therapy and Peer-Group Support. GIPA program and activities through Peer Support Group included treatment consultation; drug compliance supervising service; home visit and hospital visit; socialization of HIV/AIDS to the community and sharing activity. The stakeholders contributed to the HIV/AIDS management program, particularly in the terms of program implementation policy, structure, and process, thereby it could run well through good cooperation, coordination and communication among the stakeholders on the basis of mutual interest and objective.
\end{abstract}

Keywords: stakeholders, comprehensive and sustainable service, PLWHA, HIV/AIDS management

\section{Introduction}

People Living with HIV/AIDS (PLWHA) deserve health life and need health support and care. In addition, PLWHA can also be involved in health care, whether promotive, preventive, curative or rehabilitative (WHO, 1969, 2010, 2011, 2012; National Working Positive Coalition, 2009). Eradicating HIV/AIDS, Tuberculosis and other diseases is a global consensus in Millennium Development Goals of September 2000 and Indonesian national commitment. In Indonesia, since HIV/AIDS case was found for the first time in 1987 in Bali, HIV/AIDS development arrives at worrying level today. As suggested by Directorate General of Diseases Control and Environment Sanitation of Health Ministry of Republic of Indonesia, cumulatively there were 98,390 HIV/AIDS cases in the period of April $1^{\text {st }}$ 1987-December $30^{\text {th }}$ 2012: 42,887 AIDS case and 8,235 deaths. The cumulative number of AIDS case by sex in the period of April $1^{\text {st }} 1987$-September $30^{\text {th }} 2012$ was 42,887 
cases consisting of 23,702 males, 12,338 females and 6847 unknowns. The cumulative number of AIDS case by risk factor in the period of April $1^{\text {st }}$ 1987-December $30^{\text {th }} 2012$ included 25,534 heterosexual, 1009 homo-bisexual, 7752 Injection Drug Users (IDU), 85 blood transfusion, 1158 perinatal transmission and 7116 unknown cases. That by age group in the period of April $1^{\text {st }} 1987$-December $30^{\text {th }} 2012$ included 158 cases for $<1$ year, 756 for 1-4 years, 325 for 5-14 years, 1408 for 15-19 years, 15,093 for 20-29 years, 12,044 for 30-49, 4270 for 40-49, 1252 for 50-59, and 404 for $>60$ years groups, and 7176 unknown cases.

In Health Pocket Book of 2012 about the Visual Data of Health for Central Java Province in the second quarter of 2012, it is stated that HIV/AIDS data of 2012 consisted of 184 HIV and 230 AIDS cases. AIDS Management Commission of Surakarta City states that in the period of October 2005-June 2013 there were 1,055 HIV/AIDS cases in Surakarta consisting of 371 HIV, 684 AIDS cases and 353 deaths. Generally they were treated in Dr. Moewardi (314 cases) and Dr. Oen (39 cases) Hospitals of Surakarta.

Originally, the group with high risk of HIV is those with certain sexual behavior, whether homosexual or heterosexual with changing partners; sexual workers (prostitutes) (Fortenberry et al., 2007) and those using unsterile needle such as the drug injection users (Baseman \& Williams, 1999). Today HIV/AIDS also infects women, wives or housewives who are faithful to their husband or partner. So the expose is not only on the groups having been stigmatized negatively so far (Goffman, 1974; Hogben et al., 2007) but also extends to the most vulnerable group, women and infants (Demartoto, 2010).

PLWHA, including those in Surakarta City, face many problems, either medical or social-cultural. Accepting the reality that we are suffering from an irreversible virus is not common, particularly psychologically (Herek, 2002). In addition, PLWHA should frequently hide their HIV status to be secured. There is discrimination risk in workplace environment, in getting service, even at home and in health care center. Moreover, the public view underestimating it and replete with scare remains to exist around PLWHA (Sontag, 1989; Green, 1995; Parker \& Aggleton, 2003). In addition, taking care of physical health becomes difficult. There is no available drug or no affordable drug available, limited medical test facilities and nursing or physician and nurses and doubtful secrecy guarantee (Julianto, 1996; Siyaranamual, 1997; Murni, 2006; Demartoto, 2006). Considering the problem background above, this social medical reality is interesting to study.

\section{Literature Review}

\subsection{HIV/AIDS}

Human Immunodeficiency Virus (HIV) is the one resulting in AIDS disease existing within the body fluid containing leukocyte, such as blood, placenta, semen or sperm, spinal cord fluid, vaginal fluid, breast milk, and cerebral fluid. Meanwhile, Acquired Immune Deficiency Syndrome (AIDS) is a set of symptoms due to the decreasing body immunity resulting from HIV virus (O'Neill et al., 2003). HIV/AIDS is transmitted through sexual intercourse, injection tool, HIV-contaminated blood transfusion and from infected mother to the fetus during pregnancy and delivery (Demartoto, 2010). The general symptoms of AIDS include: prolonged fatigue; frequently fever with higher than 38 Celsius degree temperature followed with sweating on the night without obvious cause; prominently decreasing body weight; glandular distention on the neck, armpit, thigh fold without clear cause; bluish red spot on the skin just like the symptoms of skin cancer; continuously diarrhea without clear cause; as well as white spot or wound on the mouth (Mundiharno, 1997, pp. 9-10; Watson et al., 2005).

\subsection{Stakeholders Knowledge, Attitude, and Behavior in Relation to HIV/AIDS}

The individuals or institutions in HIV/AIDS management program consists of PLWHA (including family, friends); the members of society who are care of HIV/AIDS; governmental institution; Non-Governmental Organization that is care of HIV/AIDS and the private. The stakeholders, for undertaking sustainable comprehensive service to PLWHA, should have knowledge, attitude, and behavior in relation to HIV/AIDS. Stakeholder knowledge about HIV/AIDS is what they know about HIV/AIDS as an idea system consistent with the objects and connected by a belief obtained from direct observation, conclusion result, other's testimony and authority. Stakeholder attitude to HIV/AIDS management is the tendency to respond either actively or passively to an object followed with the tendency to take some action when understanding and knowing what HIV/AIDS is and getting further information about HIV/AIDS in deciding the attitude toward HIV/AIDS, either positive or negative. Stakeholder behavior in relation to HIV/AIDS is any response to certain situation having certain meaning carried out in relation to HIV/AIDS. 


\subsection{Greater Involvement of People with HIV/AIDS (GIPA)}

Participation is a very important thing in the attempt of achieving the objective of HIV/AIDS management program. PLWHA and stakeholders should be involved and participate actively in such the activities, whether physically, materially or non-physically, to take part in decision making, planning, implementation and result utilization processes freely, voluntarily or spontaneously in order to get benefit and to achieve the objective. In Denver principle, June 1983, PLWHA declined to be designated as "victim", the term with failure sense. Only occasionally, PLWHA are designated as "patient", the term meaning helplessness, dead-end, and dependency on others. It urges PLWHA to be involved in any level of decision making. PLWHA involvement in any AIDS-related forum has equal credibility with other participant. PLWHA are entitled to die and to live in dignity (UNAIDS, 1999).

Ottawa Charter for Health Promotion on November $21^{\text {st }} 1986$ states that health promotion works through concrete and effective action by the community to determine priority, decision making, strategic planning, and applying decision to achieve better health. This core of process is the empowerment of ownership and mastery community over its own effort and destiny. The Declaration of AIDS Summit in Paris on December $1^{\text {st }} 1994$ stated supporting the involvement of PLWHA through an initiative to reinforce capability and cooperation between PLWHA network and community organization. By convincing their full involvement in dealing with HIV/AIDS at all national, regional, and global levels, the initiative will particularly stimulates the creation of political, legal and social support circumstances (UNAIDS, 1999)..

GIPA is to recognize the important input the PLWHA can give, and to create the circumstance within the society for active involvement by PLWHA in the attempt of dealing with HIV/AIDS. GIPA is a principle, not program, of not urging the PLWHA to disclose their status, of identifying PLWHA's skill and of involving the affected people as well, because AIDS is not only health issue but also the need for therapeutic compliance (O'Neill et al., 2003; Sabrawi, 2007). The GIPA's supporting activities include, among others, peer-group support, peer education, advocacy, community education, counseling encouraging compliance, program planning and implementation, public health policy and law, as well as "HIV Stop Here".

\subsection{A Sustainable Comprehensive Service}

In the National Health System, the services given to meet the public health requirement can be promotive, preventive, curative, and rehabilitative ones. The health service commonly given by individual or social institution is direct one in the form of examination, treatment, nursing, medical measure, diagnostic measure, as well as medical supporting measure. Meanwhile, other services include those supporting the direct service, administration service (Muzaham, 1995; Pohan, 2006). It is called comprehensive service. Comprehensive service involves a network among all existing resources in the attempt of providing holistic, comprehensive service and treatment, and broad support.

Comprehensive service is the attempt including promotive, preventive, curative, and rehabilitative attempts encompassing any forms of HIV and IMS services in Referral and Non-Referral Puskesmas (Public Health Center) including other health facilities and referral District/City hospital. The sustainable service is to provide HIV/AIDS and Sexual Transmitted Infection service completely, starting from home or community, to health care facility such as puskesmas, clinic and hospital and to home or community again; and during the course of HIV infection as well (from not infected to terminal stage). Such the activity should involve entire related parties, such as government, private, and community (cadre, non-government organization, peer-support group, PLWHA, family, $P K K$ [family wellbeing education], customary leader, religious leader, community leader as well as organization/group existing within the society). A sustainable comprehensive service provides supports in the terms of managerial, medical, psychological or social aspects to PLWHA during nursing and treatment to reduce or to solve the problem encountered.

The objective of promotive service in the HIV/AIDS management is to render the member of society having enough knowledge about HIV/AIDS and Sexual Transmitted Infection, thereby can be avoided from being infected by/infecting others. Curative service is the case management service for those infected by HIV, TB or Sexual Transmitted Infection including disease detection, treatment for acute or chronic condition. Rehabilitative service means the combination and collaboration of medical, social, measures, education and skill to take back an individual into the highest level of functional ability (WHO, 1969; O'Neill et al., 2003). In the context of HIV, TB and Sexual Transmitted Infection, rehabilitative health service also relates to educating patients and their family about how to avoid difficulty, constraints, and unnecessary complication. One of important aspects in rehabilitation is stigma reduction constituting the peer pressure and also social pressure. In addition, occupational and vocational therapies concerns work and skill that will empower the patients in social life better 
than it previously (National Working Positive Coalition, 2009). One objective of rehabilitation program is to reduce physical, psychological and social-societal disabilities.

\subsection{Structuring Theory}

Anthony Giddens calls an individual a human agent. Community is not objective reality occurring coincidentally, but created by its members' actions. The action of creating community is clearly a skilled appearance. Giddens explains the community with the concept of agent and structure. The meaning of agent is similar to that of individual, but agent refers more to an active character of individual. Gidden uses agent or actor in interchange, having inherent aspect concerning what they do or the capacity to understand what they do while doing something. Every human being is a purposive agent, because as an individual, he/she has two predispositions, that is, having reasons for their action and then elaborating these reasons continuously and repeatedly. Individual also does action as something purposive, intentional, or having motive (Giddens, 1984, 1991, p. 4).

Human action is like a continuously behavior flow such as cognition, supporting or even breaking as long as mind is still conferred to him/her (Giddens, 1991, p. 4). Structuring contains three dimensions. The first is interpretation/understanding, stating how an agent understands something. The second is morality or appropriate direction, stating how that thing should be done. Thirdly, power in action, stating how the agent achieves a desire (Giddens, 1984). Human does action intentionally to accomplish his/her objectives, at the same time human action has unintended consequence of structure establishment affecting the subsequent human action. Human, according to this theory, is a purposive agent or actor having reasons for his/her activities and is able to elaborate those reasons repeatedly (Giddens, 1984, 1991, p. 4).

It is possible that the reason the man elaborates repeatedly has purpose based on what he/she will needs at different spatial and temporal dimensions. It can be stated that an agent's action often affects the structure in which they are playing his/her part. Such these human social actions are recursive in order to make those social activities not undertaken by the social actors but created to express themselves as actors by continuously utilizing entire resource they have. In and through their activities, the agents reproduce some conditions enabling the activities to be done. Human action is like a continuously behavior flow such as cognition, supporting or even breaking as long as mind is still conferred to him/her (Giddens, 1991, p. 4).

\section{Research Methods}

This study is a qualitative research conducted using an exploratory research method. This study was taken place in Surakarta city because there are individuals and or institutions related to the HIV/AIDS prevention and management program: PLWHA (including family, friends), neighbor, surrounding people, health care personnel, hospital, non-government organization, religious leader, journalist, government and private. The sampling technique employed in this research was purposive sampling, selecting the sample with certain criteria considered as having ability to provide data maximally (Denzin \& Eds, 2000). Techniques of collecting data used in this research were in-depth interview, non-participatory observation, documentation, and Focus Group Discussion.

In this research two types of data were provided, primary and secondary ones, analyzed deeply using an interactive model of analysis consisting of three main components: data reduction, data display, and conclusion drawing (Miles \& Huberman, 1994).

\section{Result and Discussion}

Surakarta City grows into a dynamic urban area with complicated urban problems such as health (HIV/AIDS), environmental, demographic, city spatial layout, transportation, criminality, demographic dynamic, and other social problems. Surakarta City has a variety of health facilities including 11 general hospitals, 2 mental hospitals, 13 maternal hospitals, 38 clinics, 14 Puskesmas (public health centers), 25 Puskesmas Pembantu (subsidiary public health centers), 17 Puskesmas keliling (mobile public health centers), 584 Posyandu (Integrated Service Post) and 138 pharmacies. Out of them, the ones providing Voluntary Counseling and Testing (VCT) are Dr. Moewardi, Dr. Oen Hospitals, Puskesmas Manahan and Puskesmas Sangkrah.

\subsection{The Characteristics of Informant and PLWHA}

Titik Kadarsih is the Head of Disease Control and Sanitation Division of Surakarta City's Health Office, the one competent in illumination about HIV/AIDS and drugs among the students and the public. Harsojo Soepodo is the Secretary of AIDS Management Commission of Surakarta City since 2010.

Endang Listiani is the Chairwoman of LSM Solidaritas Perempuan Untuk Kemanusiaan dan HAM (Spekham = NGO of Woman Solidarity for Humanity and Human Rights) (thereafter called LSM Spekham). LSM Spekham 
is currently having HIV/AIDS management program in Klaten Regency along with Global Fund (GF) NU R-9 for the population with high risk of being infected by HIV/AIDS, prostitutes, homosexual, Men who have sex with men (MSM), High Risk Men (HRM) and PLWHA. Yunus Prasetyo is the chairman of LSM Mitra Alam Program having Harm Reduction Program for HIV/AIDS management for Injection Drug Users (IDU's).

Putut Hermawan is the chairman of LSM Gerakan Sosial Advokasi and HAM untuk Gay (Gessang) in Surakarta. LSM Gessang is currently cooperating with GWL-INA for such programs and activities as HIV/AIDS socialization in MSM community, promotive Indonesian Website play safe from HIVOS of Netherlands in Car Free Day activity every Sunday at 06.00-09.00 a.m. along Slamet Riyadi Street of Surakarta. Suwito is the case manager of LSM Gessang in charge of attending HIV/AIDS-positive MSM in Surakarta City.

Agus Badrulloh Zaman is the man with HIV serving all at once as the Head of Solo Plus Peer Support Group in charge of directing the Solo Plus activities aiming to provide psychosocial support to PLWHA. Garis Subandi is the one with HIV having open status. He knew his HIV + status since 2006 due to putaw type of drug injection when he was in the third grade of Senior High School. He was only 18 years old at that time. The type of drug he tried for the first time was pil koplo or inex (ecstasy). When he was starting to study at college he started to use putaw by means of burning it on a metal contained, and then inhaled the smoke resulting from the combustion that made him "fly". Because of his friends' persuasion, he was then dared to take putaw by means of injection. He dissolved putaw into some water on a spoon, and then suctioned it into syringe and injected it into the hand. He did it three times a week. He develops pulmonary diseases and coughs frequently. Now he is active in Solo Plus activity to give psychosocial support to PLWHA newly knowing their HIV + status.

Sandi is a student of one Private College in Surakarta City. Sandi knew putaw since he was in Senior High School with the reason to try it only and he still consumes it until today without his family members' recognition because he does it in his boarding house. Sandi gets putaw from a dealer whom he has been long familiar with. He consumes putaw along with his friends in his boarding house. The way of consuming putaw is by dissolving it first into water and injecting it into the body, and then suctioning the blood and injecting it again into his body to get maximum satisfaction. Sandi has known his status as the one developing HIV since 2009. He frequently feels tired. Now Sandi is active in Solo Plus activities to provide psychosocial support to his fellow PLWHA.

Sunarti is mother of someone with AIDS. Originally, she did not know if her child had been infected by HIV/AIDS. She thought that her child only suffered from prolonged diarrhea and he lost weight dramatically. Gianto is the one with AIDS from gay community. He is 30 years old. He has known his HIV + status since 2010 He states that in the past he often changed partner in sexual intercourse with same sex. His health condition is very saddening; his body is very thin with so many pimples and he always feels itchy throughout his body.

Tiyas is the one with AIDS from homosexual community. He is 27 years old and has known his HIV status about one year ago. Tiyas is a homosexual prostitutes usually occupying around Tirtonadi bus terminal of Solo. Now he no longer vends himself because of acute TBC he suffers from. Rukmi is a 32-years old housewife with two young children. She was infected by HIV/AIDS from his husband, the one with HIV from IDU community and she is very depressed.

Sukma is a 35 -years old woman with HIV. He worked as prostitutes usually occupying in Gilingan close to Tirtonadi Bus terminal of Solo in the past; she is symptomatic relating to AIDS. Putri is the one with AIDS, the former prostitutes. She is 37 years old. Putri was usually occupying around Republic of Indonesia Radio Office of Surakarta City. Putri often develops prolonged diarrhea.

\subsection{Promotive, Preventive, Curative and Rehabilative Service in HIV/AIDS Management Program}

Surakarta City's Health Office serves as the provider of Voluntary Counseling and Testing service, HIV/AIDS treatment and therapeutic service of Rumatan Methadone. In Surakarta City, there are two Puskesmas providing VCT service: Puskesmas Sangkrah and Puskesmas Manahan. The PLWHA of IDU treatment are referred to Puskesmas Manahan, while the other risky populations to Puskesmas Sangkrah. VCT activity, according to the Head of Surakarta City's Health Office, is important because it is the entrance gate into all of HIV/AIDS medical services including Antiretroviral Therapy (ART) service and Opportunistic Infection prevention as well as the prevention of transmission from mother to children. Other services include psychosocial service, healthily living behavior counseling and facilitating access to a variety of health service the client needs.

VCT activity has Counseling, Consent and Confidential (3C) principles. Counseling is an aid process in which an individual, sincerely and with clear objective, devotes time, attention and skill to help the clients learn their own condition, recognize and solve their problems against the limitation imposed by the environment. Consent means to provide information completely concerning HIV/AIDS by the trained health officers to the 
patients/clients to make them understanding, before they give informed consent for some medical measures. Such the information is conveyed by the examining physician with a language acceptable to the patient. Counseling should be taken by every patient, while testing is carried out with the patient's permission. Informed consent is given in spoken and written form containing the patient's agreement. Confidential means that the secrecy of information given and test result conveyed is the main part of HIV testing procedure. The service should be professional, appreciate the client's right and dignity. All information conveyed by the client is kept for its confidentiality by the counselor and health officer, not allowed to be discussed out of the client visit context. All written information should be stored in unaffordable place for those undeserved. Information about client can be known only for the client's interest and on his/her permission. This statement is supported by Garis Subandi and Sandi, the ones with HIV from IDU and other HIV/AIDS patients such as Gianto, Tiyas, Sukma and Putri.

The Health Office of Surakarta City provides and gives high-quality medication and treatment for PLWHA, integrates AIDS medication and treatment services for PLWHA into general health treatment providing, and HIV infection prevention program, develops a nursing series/unit approach for HIV among the PLWHA. For an individual having undertaken VCT and known that he/she is positive HIV, she/he will be recommended to have medication immediately by attending ART, the medication therapy with three combined Antiretroviral (ARV) drugs aiming to reduce the number of virus and virus replication in the blood of people with HIV/AIDS and to increase the CD4 cell level in the body of people with HIV/AIDS. The types of drugs used include AZT, 3CT and Nevirapine. These drugs costed about IDR 600,000 to IDR 700,000 in the past but it is free now. The objectives of ARV therapy are to reduce morbidity and mortality due to HIV, to improve standard of living, to recover and to maintain immunity function, and to suppress the virus replication as maximally as possible in long term. ARV should be consumed in a lifetime by HIV/AIDS patient and needs very high compliance in order to prevent virus resistance from occurring in the body of HIV/AIDS patients.

The Health Office of Surakarta City provides Opportunistic infection treatment service, the treatment service for the virus-, bacteria-, parasite-, or fungus-induced infection due to the decreased body immune of HIV/AIDS patient. Rumatan Methadone therapeutic service is the one provided specifically to the injection drug users. Rumatan methadone program provides and gives legal medication consumed orally (by means of drinking) as the substitute for illegal one/Narcotic, psychotropic drug and substance (or called Napza), consumed by means of injection. The objectives are to mitigate the adverse health, social and economic effects for everyone and community rather than to circulate illicit drugs, psychotropic, and other addictive substances; to mitigate the risk of being infected by and of infecting HIV/AIDS as well as other diseases transmitted through blood (Hepatitis B and C); to mitigate the overdoses risk and other health problems; to switch injected substance to non-injected one; to reduce the use of risky napza, such as using injection tool collectively, and using various napzas simultaneously, injecting tablet or filtered first; evaluating the client's health condition daily and giving referral and treatment counseling. Methadone is administered daily to putaw addicted to be consumed under the physician's supervision. This therapy's objective is to stop putaw use, to reduce injection frequency, and to enable IDU to live healthily and productively. This therapeutic service is provided in Puskesmas Manahan.

AIDS Management Commission (KPA) of Surakarta City has been established since 2005 in charge of coordinating all members of KPA in the attempt of HIV/AIDS management in Surakarta City; of holding coordination meeting once in a month with all members of KPA as well as recapitulating the data from NGO, sexual-transmitted infection and VCT clinics; of providing health care for HIV/AIDS infected victim in collaboration with the stakeholders; of establishing and directing Peer Support Group as peer educator to deliver information concerning HIV/AIDS, for example, a gay becomes peer educator for other gays; of holding training periodically for peer educator; of preparing case manager who monitors PLWHA specifically and develops accountability report to the Mayor at Local level and to the Governor at Provincial level.

LSM Mitra Alam is a non-government organization oriented to the empowerment of vulnerable community relying on both individual and group approach. The programs and activities of LSM Mitra Alam, among others, include HIV prevention campaign to adolescents, injection drug users, and prisoners in penitentiary; HIV prevention campaign through action, contemplation and lecture/illumination; IDU group attending; primary health care and VCT referral; promotion and distribution of condom and sterile injection needle; the reinforcement of PLWHA through Case Manager service, Solo Plus Peer Support Group and policy advocacy.

LSM Mitra Alam has Harm Reduction Program in the form of Outreach conducted actively to IDUs, either individually or in group. The field workers identified the location where IDUs usually assemble, interacted directly with IDUs, and then made an IDU population mapping. The objectives of outreach was to map IDUs populations in Surakarta City, to facilitate in providing Communication, information and Education (CIE) to IDUs, to invite IDUs to reduce the risk of injected drug using behavior through the possible attempt of mitigating 
the risk of HIV/AIDS transmission among IDUs. CIE are the HIV/AIDS information providing program among IDUs. CIE media included pamphlet, poster, bulletin, picture, sticker, video, and other forms accessible to IDUs. These information media were distributed to the sites where IDUs usually assembled. CIE contained information on the danger of HIV/AIDS, transmission mode, and how HIV cannot be transmitted, HIV treatment and its opportunistic infection; in addition it also contained the appeal to abandon the risky behavior of sharing injection needle. The objectives of CIE program include, among other, to improve knowledge that can encourage the behavior change in mitigating the risk of being infected by HIV; to provide and to supply correct and effective information and to prevent the HIV/AIDS transmission through media message.

The Risky Behavior Assessment Program aimed to reinforce and to establish the implementation of HIV infection risk mitigation carried out during outreach. This assessment was carried out to introduce the risk-reducing message and to support the behavior changing attempts. The assessment of risk reduction was conducted by means of giving IDUs the form containing some questions about their risky habit and behavior, either individually or in group. Having the form been completed by IDUs, the field workers would assess how risky the IDUs behavior was. When it was considered as very risky, IDU would be recommended to attend VCT process. It is just like what Sandi, the one with HIV from IDUs community, said.

VCT program is one of programs serving as the entrance gate into entire sustainable HIV/AIDS health care. This program is HIV test program to IDUs aiming to find out the HIV status of IDUs, to encourage the behavior change that can prevent HIV transmission among IDU, to improve PLWHA health, including in the attempt of looking for treatment for opportunistic infection for PLWHA, to plan the future in relation to family and other commitment, as well as to provide the opportunity of preventing the HIV transmission from occurring. LSM Mitra Alam collaborates with Puskesmas Manahan and Dr. Moewardi Hospital as the referrals.

LSM Mitra Alam has an injection needle sterilization program to reduce the number of infectious virus in the used injection needle in order to reduce the probability of virus transmission, such as sterilizing the injection needle to remove contaminated blood from the needle; sterilizing the injection needle using sterilizing chemical liquid; or sterilizing the injection needle by heating it. The Sterile Injection Needle program is the attempt of providing sterile (new) injection needle, education and information about HIV transmission, and referral to medical access. This service provides and gives sterile injection tools, as well as other risk-reducing materials, to the people with HIV/AIDS from IDUs community, to ensure that every injection is carried out with new needle. The objective is to reduce the adverse effect of drug use by PLWHA and to prevent the HIV prevention among IDUs.

LSM Mitra Alam has a substituting therapy program particularly aimed to PLWHA addicted to putaw/heroin. This target of therapy is to reduce criminal behavior, to prevent HIV/AIDS transmission, to preserve productive living and to stop the routinely injection drug use habit. The substitution used is methadone, a legal drug-like substance used by means of drinking and has similar effect to putaw and morphine. In this program, LSM Mitra Alam in collaboration with Puskesmas Manahan and Dr. Moewardi Hospital reminds that this therapy should be under medical supervision and cannot be carried out haphazardly and should be connected to ARV maintenance.

The HIV Medication and Treatment program is particularly intended to the HIV-infected IDUs group because of a high mortality rate due to the causes not relevant to HIV infection such as pneumonia, liver disease (Hepatitis $\mathrm{B}$ and C) and overdoses. It may occur because the HIV/AIDS patient's body immunity system weakens leading to easily disease attack. This program includes some treatment with ARV and opportunistic infection therapy. It aims to provide and to give high-quality medication and treatment for IDUs living with HIV/AIDS; to integrate AIDS medication and treatment service for IDUs into general health treatment providing and administration. The activities in this program include the freely ARV administration to HIV/AIDS patients from IDUs community. $\mathrm{ARV}$ acts to retard the course of disease, to increase the number of CD4 cell and to reduce the number of virus in the blood. The ARV begins to be administered when CD4 number is $200-350 / \mathrm{mm}^{3}$. Before initiating ARV therapy, PLWHA was given counseling about the compliance with use mode, side effect, dangerous sign and everything related to therapy in order to prevent the resistance from occurring. The procedure includes the counselor proposed ARV initiation with three combined drugs, frequently called highly active antiretroviral therapy, encompassing two drugs from NRTI class and one from NNRTI or protease inhibitor (PI) class. NRTI currently available includes AZT, 3CT, ddl and d4T. Two NRTI combinations frequently recommended are AZT $+3 \mathrm{TC}$ and $\mathrm{d} 4 \mathrm{~T}+3 \mathrm{TC}$. 
LSM Mitra Alam provides Case Manager as the drug consuming supervisor for PLWHA recalling that this ARV really requires high compliance with drug consumption. LSM Mitra Alam cooperates with Puskesmas Manahan and Dr. Moewardi Hospital as the treatment referral. PLWHA from IDU are frequently in bad health condition due to narcotic, psychotropic, and other addictive substance uses. Their meal becomes inadequate and their environment condition unhealthy. However, many PWLHAs from IDU reluctantly use primary and public health services. In addition, there is a fear within them of being known for narcotic, psychotropic, and other addictive substance use, and then of encountering legal process and discrimination. Departing from that, LSM Mitra Alam provides primary health services such as abscess treatment, referral to appropriate service corresponding to HIV/AIDS patient from IDUs community's needs.

Solo Plus is an independent peer-group for PLWHA in Surakarta City and surrounding established as the response to the psychosocial support need for the HIV-infected people and the affected family. Solo Plus aims to strive for right equality, opportunity, and health care access and support as well as the removal of stigma and discrimination against PLWHA. The platform of Solo Plus Peer-Group includes: firstly, the improvement of organization and Peer-Group member's capacity by encouraging the members of Peer Group to attend training held by many parties, psychosocial support for new PLWHA and members; monthly routine meeting; the delivery of session information from many parties (psychiatrist, herbalist, VCT and so on); and the involvement of all PLWHAs in Surakarta City area and surrounding to be the member of Solo Plus Peer Group as well as the member database updating. Secondly, it includes policy advocacy and creating public awareness through audience with the government of regencies in Solo Raya related to PLWHA support; initiating satellite peer-group in Surakarta City and surrounding to facilitate the local government's support; getting involved actively in HIV prevention campaign in the world's AIDS day and AIDS Contemplation Night; direct socialization to the public in distributing information about HIV and AIDS as well as conducting testimony in various events. Thirdly, supporting CST service to PLWHA with case management (VCT, CST, Jamkesda (Local public security) referring; CD4 test, liver and renal function test, PMTCT; Food Supplementation for PLWHA facilitating PMTCT for the members; attendance for children living with HIV/AIDS (CLWHA); attendance for PLWHA in penitentiary and visiting PLWHA at hospital and at home (giving the spirit of living, encouraging them to open their status and to change their behavior). Fourthly, it develops network and encourages the livelihood sustainability of peer-group's members by contacting the related parties (Government, NGO, private); individual or group business capital stimulant aid; establishes Solo plus Peer-Group pre-cooperative as well as facilitates the life skill training for its members.

SpekHam stands for Woman Solidarity for Humanity and Human Rights. The target of LSM SpekHam is to eradicate the violence against women, to meet the women's basic needs, and to minimize the number of marginalized and exploited women so far. Its main program is, in addition to giving attendance for preventive attempt, is to give advocacy to the government. LSM SpekHam has HIV/AIDS management program in Surakarta City with the risky women as the target and the prostitutes and the women becoming the victims of men behavior as the client. SpekHam facilitates the condom outlets in prostitution area and mobile clinic in collaboration with Puskesmas Manahan and Puskesmas Sangkrah of Surakarta City. Every month SpekHam reports to AID Management Commission (AMC) about the program it undertakes, prostitutes achieved and condom use.

LSM Gessang deals with HIV/AIDS in MSM in Surakarta City through outreach carried out to MSM by providing information face-to-face between the field workers and both commercial and non-commercial gays about the hazard of HIV/AIDS, giving brochure, leaflet and sticker and finding out the meaning of such information media's content. The distribution of condom and lubricator and the establishment of condom outlet in the bases of gay community, either commercial or non-commercial, such as in stalls, beauty salon, café, night club, and the places where the gay communities assemble in Surakarta. LSM Gessang carries out cyber outreach particularly introvert gay who looks for his sexual partner through internet. There are some field workers from LSM Gessang specifically chatting to give information about HIV/AIDS, information about where they can take VCT, Sexual Transmitted Infection examination and get condom. LSM Gessang also developed a Web Site specifically for gay community as well as Hotline Service around HIV/AIDS and sexuality for the gay. Edutainment is a program for gay to make creation in art performance such as singing, fashion show, drama and dancing and to socialize about HIV/AIDS all at once. Sportainment is a program integrating sport and entertainment connected to HIV/AIDS in the form of poster, and etc. Mobile clinic is desirable because the gay community is still shy to go to Sexual Transmitted Infection and VCT clinic with the reason that their identity will be known by others. The procedure of mobile clinic is by inviting and assembling the gays into some place there is a counselor coming from the gay community, and then data collection and counseling are carried out in 
the mobile clinic and then the result is brought to the hospital or Puskesmas. There are Peer Educators in serving as information provider to other gay about HIV/AIDS, for example: the gay from fellow model, designer, dancer, artist, or students groups, out of them one person will be taken for each group to get training to be a PE, in order to give HIV/AIDS information to their own group, and to give the report on outreach result from their group to LSM Gessang. Meanwhile, the Case Manager and the Peer Support Group are the attendants for the HIV + gay in order to control their life.

Himpunan Waria Solo (HIWASO) (Solo Homosexual Association) is a NGO specifically protecting the homosexual community in Surakarta. The program carried out by HIWASO includes socialization, lecture and illumination about HIV/AIDS, Sexual Transmitted Infection and VCT screening as well as freely condom distribution to homosexuals.

Yayasan Kakak (Kakak Foundation) is a NGO operating in child right protection and realization particularly the right of child as consumer, the child as exploitation and sexual abuse victim. In the attempt of contributing to decreasing HIV/AIDS transmission rate in Surakarta City, Yayasan Kakak carries out attendance to the children as the victim of Children Commercial Sexual Exploitation, gives reproductive health education; gives them the opportunity of taking counseling and provide health care. Yayasan Kakak also undertakes socialization to the public through radio broadcasting, public opinion in local newspaper, or becomes the presenter in broadcasting or seminar about HIV/AIDS, particularly for the child as the victim of Child Commercial Sexual Exploitation.

\subsection{The Application of GIPA}

In Surakarta City, PLWHA could participate in the HIV/AIDS management program, through Solo plus Peer-Group Support. The activity of Solo Plus includes providing psychosocial support to PLWHA and treatment consultation, monitoring the health progress of PLWHA, socializing HIV/AIDS. In addition, Solo Plus was established to enable PLWHA to cooperate in group to remove the stigma existing within the society. The role played by Solo Plus in relation to PLWHA treatment including through treatment consultation and Drug Consumption Supervising Service. Solo Plus provides consultation service for PLWHA concerning ARV medication and opportunistic infection arising within the PWLHA. In this consultation, the PLWHA's condition is also monitored from the increased CD4 in PLWHA's blood to the level of compliance with drug consumption for PLWHA. Because ARV therapy should be taken with high compliance, Solo Plus provides Drug Consumption Supervising service functioning to remind PLWHA and their family to take the drug diligently to prevent the resistance from occurring inside the PLWHA. Such the activity is conducted by means of delivering SMS or calling PLWHA to remind them about ARV taking, while if PLWHA is in Solo Plus and forget to bring the drug, Solo Plus has provided it. Home Visit and Hospital Visit are the activities of visiting PLWHA who are treated at both home and hospital. This activity functions to give the PLWHA and their family the motivation to live psychosocial support.

Meanwhile, the activities beyond treatment are conducted through socializing HIV/AIDS to the society and sharing activity. In these activities, PLWHA are involved to give appropriate understanding about what HIV is, how it is transmitted, and to socialize about the rights of PLWHA. This activity started from transferring knowledge about HIV to the society by PLWHA and then was closed by a statement that those giving knowledge are PLWHA, thereby breaking the assumption that PLWHA live unhealthily. Sharing activity is the activity of assembling for PLWHA with all risky behaviors held every last Sunday in the end of month. This activity is the one of sharing experience among PLWHA concerning their disease and how to cure it, in addition in this activity, there is also a forum to share problem arising within those developing HIV/AIDS that will be solved jointly later.

\subsection{A Sustainable Comprehensive Service Model on PLWHA}

A sustainable comprehensive service is the government's attempt of making the HIV/AIDS-and Sexual Transmission Infection-related services close to the people requiring it. HIV test and counseling service, Sexual Transmitted Infection management, TB-HIV collaboration, the prevention of transmission from mother to child, ARV treatment and opportunistic infection, rumatan methadone therapy and sterile injection needle service can be carried out by all health care facilities, from primary, secondary to tertiary service. The services are given comprehensively, from promotive, preventive, curative, to rehabilitative (O'Neill et al., 2003).

The performers of sustainable comprehensive service in HIV/AIDS management is PLWHA including family; friend; members of society caring about HIV/AIDS; government institution, non-government organization and private caring about HIV/AIDS. The involvement of stakeholders to provide support, help and attendance to PLWHA. This role of stakeholders highly affected the PLWHA's survival, health and wellbeing. Without the stakeholder participation in the sustainable comprehensive service to PLWHA. PLWHA health cannot be secured (O'Neill et al., 2003; Watson, 2005). 
The sustainable comprehensive service to PLWHA in Surakarta City was carried out through collaboration process. The collaboration established between the performers of sustainable comprehensive service and the PLWHA affected positively the PLWHA. It could create a dynamic sustainable comprehensive service. The performers have a complicated partnership and communication relationship. The collaboration established is the one based on the reason that they share same interest and objective.

In addition, individual and or institution in providing a sustainable comprehensive service to PLWHA always have intensively interaction time through routinely meeting according to the need (once a month) to discuss whatever related to a sustainable comprehensive service to PLWHA. Every individual and institution with more experience and knowledge will share their scholarship and experience to all members (partners). For that reasons, the sustainable comprehensive service to PLWHA in Surakarta City develops significantly.

It is consistent with Anthony Gidden's structuring theory that every human being is a purposive agent. These performers have the same purpose and objective to be achieved in a sustainable comprehensive service to PLWHA in Surakarta City through interaction process, collaboration and coordination each other in order to achieve the objective as expected. Interaction is carried out routinely and repeatedly. Thus, the partner in a sustainable comprehensive service to PLWHA will give feedback in social interaction, collaboration and coordination processes occurring among the performers of sustainable comprehensive service to PLWHA.

The structure of sustainable comprehensive service to PLWHA in Surakarta city is created in the presence of continuously established social interaction, collaboration, and coordination among the stakeholders. Such the structure occurs because there are infrastructures and human resources that potentially make the sustainable comprehensive service to PLWHA in Surakarta City better. It is mentioned in social interaction in the presence of collaboration occurring periodically and useful for all parties. Social interaction is the main activity in sustainable comprehensive service to PLWHA in Surakarta City. In the absence of social interaction, all of those related to the sustainable comprehensive service to PLWHA will not know what happened.

Social interaction among the performers of sustainable comprehensive service to PLWHA is an action carried out among PLWHA including family; friend; members of society caring about HIV/AIDS; government institution, non-government organization and private caring about HIV/AIDS. They are human agent with the result achievement of social interaction they perform, that is, the improvement of the PLWHA's living prosperity quality and health (O'Neill et al., 2003; Mbonu et al., 2011)

PLWHA also deserve healthy life. No one wants to be sick or infected by anything the medicine of which has not been found. When there is an individual affected by this disease, it is the evidence that the prevention measures implemented has not reached everyone or has not been appropriate. For that reason, the HIV + prevention measure cannot be stopped in prevention only. But, it should be coordinated with the attempt of providing support and service for those infected. Even it should be taken into account what should be done if this support and service is not given duly, for example by breaking the ethical code, given discriminatively, or even is not given at all. Viewed further, one consequence of increasingly intensive HIV/AIDS prevention campaign is that many people feel the need for testing themselves voluntarily. Moreover, those whose status has been known from the typical AIDS clinical symptoms, or surveillance the identity of which leaks to the corresponding people. So, there should be support and service programs for those who have been tested, with either positive or negative results (Murni, 2006).

The result of research showed that in Surakarta City, individual or institution caring about and related to HIV/AIDS have attempted as optimally as possible in providing sustainable comprehensive service through GIPA in HIV/AIDS management program. Support and service for PLWHA have been actually begun since they have known their HIV status corresponding to HIV test principles included in national AIDS management strategy, namely informed consent (with knowledge and awareness) from the corresponding people, counseling should be given before and after test, and confidentiality should be upheld. All of them highly affect their physical and mental health later. Unfortunately, these three principles are still broken frequently in the field. Some people are still tested without their knowledge and permission. How do we feel when we are informed that we are infected by HIV (even often wrongly called "suffering from AIDS")? The pretest and posttest counseling is not provided in discipline manner. Pretest counseling prepares the people who will take the test. Meanwhile the post-test counseling is very vital, because it is the first information and understanding an individual brings home after he/she gets diagnosis. Going home by bringing the diagnosis of severe disease without adequate understanding will lead to adverse consequence, from depression to, more fatally, suicide attempt. Similarly, the secret leakage will lead to disturbed social relationship and unnecessary discrimination (Ross, 2004; Hogben et al., 2007). 
The effect of these violations may be common in nature or even very personal, including the effect on physical health, mental health, finance (for example spending entire for antiretroviral treatment without sufficient information), family relationship, sexual relationship, marriage, child, security, survival (not understanding asymptomatic phase and productivity), to problems during demise (the eradication of clothes, bedcover, excessive plastic use, and so on). Included here is the effect on the transmission prevention measure (Ross, 2004). The empowered PLWHA who get counseling will be able to take care of others (sexual partner, health personnel, injection needle/tindik (ear holing)/tattoo users, and his/her infant) from the transmission just like he/she takes care of him/herself.

If an individual is ill, the main thing he/she should look for is curative medication to recover. It is true for all diseases. So is for HIV. However, the reality the HIV + people should face is the absence of curative medication (drug). The very big expectation is always relied on antiretroviral drugs. Despite immature, these drugs have been evidently able to decrease the virus level in an individual's blood until undetected. These drugs are still under investigation. Firstly, these drugs are unaffordable to the public. Secondly, the procurement is not even and cannot be ensured for its presence/absence. Thirdly, the facility and ability of monitoring over this drugs' effect is still very low. For example, with test viral load: the expensive test leads to the low number of clients in laboratory, the officers become less trained there and reagent becomes expired. Fourthly, up-to-date and balanced information about these drugs is still insufficient (O'Neill et al., 2003).

Information can help people with HIV in making deliberations to make the best decision later for themselves and others. When an individual is rich of information, it is easier to him/her to make deliberation and decision anywhere she/he is. In addition, vital counseling should be combined into test as one package and it should be provided in more discipline manner. There should be not a test without counseling. Counseling can be taken after the test "package" is completed, as long as the people need it. The challenge here is that such the counseling is uncommon. People consulting with counselor or psychologist are frequently stigmatized as "in trouble" and tend to be seen negatively, even by those requiring.

The first and frequently only contact with HIV + people is the health personnel examining them. Then several times in their life, they will contact again the health personnel. The health personnel then becomes role model for the public and other service provider about how to treat HIV + people because they are considered as knowledgeable. The less information and understanding from the health personnel gives a space for the excessive fear and discrimination, from confidentiality underestimation to refusal against treatment. It affects the physical and mental health. There should be an improvement in the treatment ethic practice among the health personnel. There should be an empowerment among the patients, to make them understanding the presence of ethic. Thus, they can take more active part in their treatment process without high dependence. In HIV + people in which their body immunity to resist disease is low, the diseases take the opportunity, thereby called opportunistic disease. In those having entered AIDS stage, it is this disease that results in death.

PLWHA also needs non-medical therapy such as herbal medicine, massage, acupuncture, and cultivating medicinal plants. The development of these therapy for HIV/AIDS should be supported and encourage in order to fill in the medical medicine vacuum. For many Indonesian people, religion has also been a kind of therapy, as well. It should be developed for HIV/AIDS (Darmaputra, 1996). In addition to non-medical therapies mentioned above, many types of therapies can be explored and studied further. For example, meditation, art therapy (e.g., music), proportional exercise, nutrition regulation, doing hobby (e.g., gardening, singing), and living healthily and in balance.

Peer Support Group is actually one of non-medical therapies. Sharing problem and thinking about the solution collectively have been long known, and makes people helped emotionally and practically. This Peer Support Group is frequently called support group, self-help group, peer support group, or PWA group. All of these have the same meaning: support group managed by and for PLWHA. Some group is special for HIV + people only, but some other involves closest people such as family, friend, or volunteer (O'Neill et al., 2003). The result of research shows that in Surakarta City there are some Pee Support Group such as Solo Plus facilitated by LSM Mitra Alam and other Peer Support Group facilitated by other Non-Government Organizations caring about AIDS. Stigma and discrimination accompanying PLWHA become important factor to the emergence of support group as the only place where they feel comfort, can escape from isolation, kept for their confidentiality, secure, and supported. The support group has a big role in the attempt of dealing with HIV/AIDS comprehensively. Moreover, the service to HIV + people has not been optimal yet. The support group becomes the agency in which support is given and treatment is provided. 
Support group becomes the place in which the education and the information distribution about HIV/AIDS occur. The support group compensates the lack of counseling service that should exist accompanying all HIV tests but not implemented. Some support groups develop into advocacy material voicing the apprehension about living with HIV/AIDS, attempting to influence the policy making, and taking a part in decision making process. No specific formula exists to establish support group, but there is one principle evidenced repeatedly. The method having evidently addressed the HIV + people's need within the group and ensured the effectiveness of this group existence is to design a client-centered program and group structure, to which the HIV + patients belongs. The design of program, activity and form is done by taking into account the capacity and limitation as well as reality of the group itself. Finally, there are two areas requiring attention from a HIV + individual: helping him/herself and making him/herself an activist who raises other HIV + people's comprehension.

The sustainable comprehensive service involves a network between all resources existing in the attempt of providing a holistic, comprehensive service and treatment, as well as broad support to PLWHA and family. The sustainable comprehensive service includes hospital treatment and home treatment during the course of disease. Before the sustainable comprehensive service is decided, several things should be taken into account including, among others, adequate resources such as fund support, material and tool, human resource, from either the government or the public, and good collaboration between them. The sustainable comprehensive service encompasses clinical management, directly sustainable comprehensive service to patient, education, prevention, counseling, palliative treatment and social support.

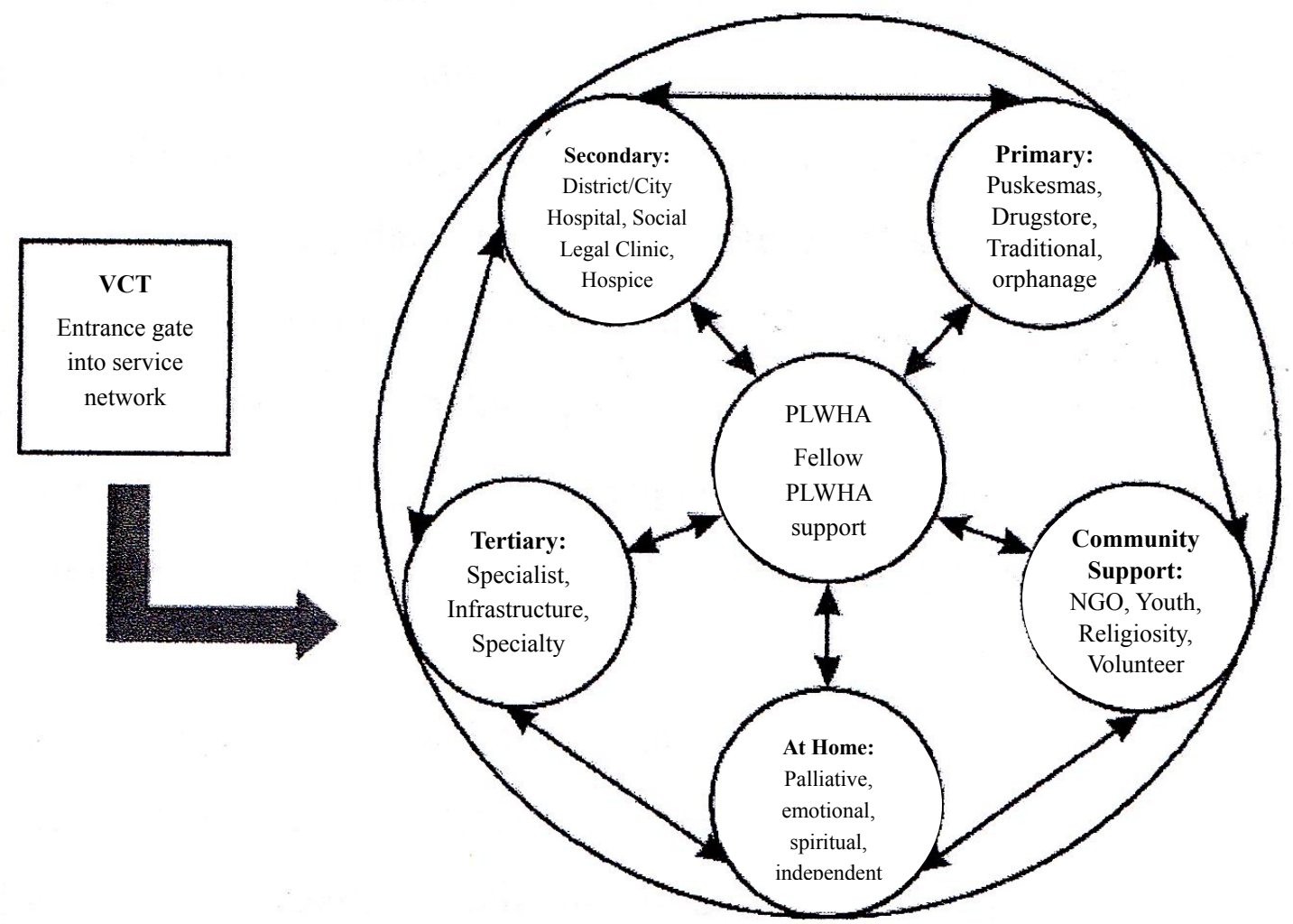

Figure 1. A sustainable comprehensive service to PLWHA

The sustainable and continuous comprehensive service concept is built on HIV/AIDS service and treatment in team collaboration and should involve several components. VCT is the starting point of a sustainable and continuous comprehensive service and treatment, and the place to which they come to question, to learn and to accept an individual's HIV status with guarded privacy that can reach and apply effective treatment and prevention measures. The clinical management of symptomatic infectious case is carried out with early adequate diagnosis, rational medication, planned discharge, and capability of referring to other service providers. The nursing care should give the patient comfort and hygiene, can control the infection well, give palliative treatment and manage the terminal case, train and education the family about treatment at home and prevent the transmission as well as promote the condom use (O'Neill et al., 2003). The treatment at home and within the society including training the family and volunteer about the nursing procedure, treats the symptoms frequently 
occurring and giving palliative treatment. Good nutrition promotion, physical and emotional support, spiritual support and counseling establish the community support group to provide emotional support to PLWHA and their attendants (O'Neill et al., 2003). In this group, it can be explored the opportunity of improving and creating income source, mitigating and removing the stigma, building positive attitude within the society toward PLWHA and family, including the health personnel in either government or private sector, and in workplace. Social support and referral to social service can deal with the residence problem, job, legal aid, and to monitor and to prevent the discrimination from occurring (Letamo, 2011). Education and training about the management and prevention of HIV/AIDS for the attendants of PLWHA (health personnel, family, neighbor, and volunteer). Establishing collaboration between the service providers (clinic, social, support group) to make the service affordable through the referral system supporting each other.

\section{Conclusion and Recommendation}

\subsection{Conclusion}

The Stakeholders in Surakarta City has attempted to provide a sustainable comprehensive service with GIPA in HIV/AIDS management program, despite not optimally. Health institution, NGO caring about AIDS and Peer Support Group in Surakarta City have paid more attention than non-health institution to the HIV/AIDS management program. The high commitment has been realized into real activity. The socialization of program is rarely carried out and the books and the guidelines about HIV/AIDS are hardly found in non-medical institution leading to low commitment with individual and or non-medical institution. The coordination between stakeholders has not been optimal, but there is an expectation for the realization of coordination between individuals or institutions caring about AIDS initiating by Health Office and Local AIDS Management Commission. The constraints with coordination is caused more by leading sector, in this case, the Health Office, considered as less proactive by other institution. It can be found the work overload in the personnel of Health Office managing HIV/AIDS program. The management attempt having run so far emphasized more on the promotive attempt, while the preventive attempt has been small in portion, and curative as well as rehabilitative efforts to PLWHA has not been optimal.

In Surakarta, the promotive health care includes health education through KIE and peer educator; the attempt of changing behavior with motivation during counseling as well as government policy supporting the comprehensive health service program for HIV and Sexual Transmission Infection. The preventive health service program in Surakarta included health screening through primary health service; communication, information and education; VCT; TB-HIV control; Sexual Transmitted Infection control; Standard alertness; post-exposure prophylaxis (PEP); HIV transmission prevention from mother to child as well as peer-education (WHO and ILO, 2007). In Surakarta City, for HIV case this service is called Care Support and Treatment (CST) or nursing, support and medication for PLWHA. The support activity and rehabilitative health service in Surakarta include drugs addiction therapy with TC, Criminon, and NA; substitution therapy (PTRM); peer educator; peer support group; addiction counseling; partner notification and counseling; independency (vocational) building and palliative treatment.

Medical problem the PLWHA encounter in Surakarta City includes opportunistic infection, symptomatic symptom related to AIDS, co-infection, body immune recovery syndrome as well as side effect and interaction of ARV drugs. Meanwhile the psychological problems rising related to HIV infection are depression, anxiety, cognitive disorder, personality disorder and psychosis. The social problems the PLWHA encounter are discrimination, isolation, stigmatization, work termination, divorce, and financial burden the PLWHA should assume. Those psychosocial and socioeconomic problems are frequently encountered by PLWHA but also by their family and friends. Some HIV/AIDS cases in Surakarta City come from the injected drug user group; thereby the service scope to PLWHA cannot be apart from the problems arising in the drug users such as addiction, overdoses, injected drug-related infection, legal problem, and etc. Thus, the service scope broadens and involves not only health service but also family and non-government organization.

\subsection{Recommendation}

The should be public perception on PLWHA becoming the main key to supporting PLWHA needs such as law protection, skill improvement, reproduction health problem solving, improvement of PLWHA's economy and etc. The public can help removing stigma and discrimination, activating themselves to exhibit their support, such as in AIDS Contemplation Night activity, helping advocacy attempt and improving the concern about PLWHA. The public can carry out the treatment program without waiting for external helps, thereby reducing the burden of the family living with AIDS. Community can mobilize their resource, so that many more activities can be undertaken without relying on donor's grant. 
PLWHA needs the government's political commitment, either national or local. The government's policy and political strategy should take into account what the PLWHA feel, what they need, what they do not need, and what circumstance they need to live healthy physically and psychologically, and so forth. Because the effective policy, service, program, and strategy are client centered, in this context, PLWHA is put at the center.

PLWHA become the important part in the attempt of HIV/AIDS because they are the ones whose living is touched and affected directly by this virus. They are the most appropriate and the deepest source of understanding about HIV/AIDS. Everyone should have this understanding, particularly those whose work relating to HIV/AIDS.

\section{Acknowledgement}

We say our gratitude to the High Education Directorate General of the Republic of Indonesia's Education and Culture Ministry for the research fund for the State College Operating Grant, namely the Decentralization Research Grant of DIPA of Sebelas Maret University from the State Income and Expense Budget of 2013.

\section{References}

Baseman, J., Ross, M., \& Williams, M. (1999). Sale of sex for drugs and drugs for sex: An economic context of sexual risk behaviour for STDs. Sexually Transmitted Diseases, 26(8), 444-449. http://dx.doi.org/10.1097/00007435-199909000-00005

Demartoto, A. (2006). ODHA, Masalah Sosial dan Pemecahannya. Journal Penduduk dan Pembangunan, 6(2).

Demartoto, A. (2010). Perilaku Laki-laki yang Berhubungan Seks dengan Laki-laki (LSL) untuk Melakukan Test HIV di Kota Surakarta. Laporan Penelitian (Tidak diterbitkan).

Denzin, N. K., \& Lincoln, Y. S. (Eds). (2000). Handbook of Qualitative Research. California: Sage Publications Inc.

Dinas Kesehatan Provinsi Jawa Tengah. (2012). Buku Saku Kesehatan 2012 Visual Data Kesehatan Provinsi Jawa Tengah Triwulan II Tahun 2012. Semarang: Dinas Kesehatan Provinsi Jawa Tengah.

Ditjen, P. P. M., \& Depkes, R. L. P. L. (2012). Statistik Kasus HIV/AIDS di Indonesia Dilapor s/d Desember 2012. Retrieved from http://www.spiritia.or, id

Epidemiological Fact Sheet. (2008). Retrieved July 5, 2013, from http://www.apps.who.int/globalatlas/predefinedreports/efs2008/full/efs2008_ngpdf

Fortenberry, J. D., Mcfarlane, M. M., Hennessy, M., Bull, S. S., Grimley, D. M., Lawrence, J., ... Van Devanter, N. (2007). Relation of Health Literacy to Gonorrhea Related Care. Sexually Transmitted Infection online.

Giddens, A. (1984). The Constitution of Society: The Outline of the Theory of Structuration. Berkeley: University of California Press.

Giddens, A. (1991). Modernity and Self-Identity: Self and Society in the Late Modern Age. Stanford, California: Stanford University Press.

Goffman, E. (1974). Stigma: Notes on the Management of Spoiled Identity. New York: Jason Aronson.

Green, G. (1995). Attitudes towards people with HIV: Are they as stigmatizing as people with HIV perceive them to be? Social Science and Medicine, 41(4), 557. http://dx.doi.org/10.1016/0277-9536(94)00376-5

Herek, G. M. (2002). Thinking about AIDS and Stigma: A Psychologist's Perspective. Journal of Law, Medicine and Ethics, 30(4), 594-607. http://dx.doi.org/10.1111/j.1748-720X.2002.tb00428.x

Hogben, M., McNally, T., McPheeters, M., \& Hutchinson, A. B. (2007). Task Force on Community Preventive Service. The Effectiveness of HIV Partner counseling and Refferal Service in Increasing Identification of HIV Positive Individuals. American Journal of Preventing Medicine, 33(25). Elsevier Inc.

Julianto, I. (1996). 11 Langkah Memahami AIDS. Yogyakarta: LP3Y.

Komisi Penanggulangan AIDS. (2012). Situasi HIV \& AIDS di Indonesia. Retrieved from http://www.icaap9.org

Letamo, G. (2011). Trends and Levels of HIV/AIDS-Related Stigma and Discriminatory Attitudes: Insights from Botswana AIDS Impact Surveys. In G. Letamo (Ed.), Social and Psychological Aspects of HIV/AIDS and their Ramifications. Croatia: In Tech Europe. http://dx.doi.org/10.5772/19380

Mbonu, N. C., Borne, B. V. D., \& De Vries, N. K. (2011). Societal Beliefs and Reactions about People Living With HIV/AIDS. In G. Letamo (Ed), Social and Psicological aspects of HIV/AIDS and their Ramifications. Croatia: In Tech Europe. 
Miles, M. B., \& Huberman, A. M. (1994). Qualitative Data Analysis: An Expanded Source Book (2nd ed.). California: Sage Publications Inc.

Mundiharno. (1997). Perilaku Seksual Berisiko Tertular PMS dan HIV/AIDS (Kasus Sopir Truk Antar Propinsi).Yogyakarta: Pusat Penelitian Kependudukan Universitas Gadjah Mada.

Murni, S. (2006). Dua Sisi dari Satu Sosok, Kumpulan Tulisan Suzana Murni. Penyusun dan Penyunting: Putu Oka Sukanta. Jakarta: Spiritia dan UNAIDS.

Muzaham, F. (1995). Memperkenalkan Sosiologi Kesehatan. Jakarta: UI Press.

National Working Positive Coalition. (2009). Employment And Vocational Rehabilitation For People Living With HIV-AIDS: A Report To The Presidential Transition Team. Retrieved July 8, 2013, from http://www.aidsaction.org/attachments/503_employmenan/vocation/for/ppl/living/with/aids.pdf

O'Neill, J. F., Selwyn, P. A., \& Schietinger, H. (Eds.). (2003). A Clinical Guide to Supportive \& Palliative Care for HIV/AIDS (2003 ed.). Washington, D.C.: Health Resources and Services Administration.

Parker, R., \& Aggleton, P. (2003). HIV and AIDS-related stigma and discrimination: A conceptual framework and implications for action. Social Science and Medicine, 57(1), 13-24. http://dx.doi.org/10.1016/S0277-9536(02)00304-0

Penyakit, D. J. P., Lingkungan, P., Kesehatan, R. I. K., Hukum, D. J. P. K., \& HAM, R. I. (2012). Pedoman Layanan Komprehensif HIV-AIDS \& IMS Di Lapas, Rutan Dan Bapas. Jakarta: Direktorat Jendral Pengendalian Penyakit \& Penyehatan Lingkungan, Kementerian Kesehatan RI, Direktorat Jenderal Penyuluhan Kementerian Hukum \& HAM RI.

Pohan, I. S. (2006). Jaminan Mutu Layanan Kesehatan Dasar-Dasar Pengertian dan Penerapan. Jakarta: Penerbit Buku Kedokteran EGC.

Ross, E. L. (2004). Pain Management. Philadelphia: Hanley \& Belfus. Inc

Sabrawi, S. R. (2007). Pelibatan Lebih Besar Orang dengan HIV/AIDS (GIPA/Greater Involvement of People Living with HIV/AIDS) Di Komisi Penanggulangan AIDS Daerah Istimewa Yogyakarta. Makalah dalam Pertemuan Nasional HIV/AIDS Ketiga. Surabaya 5-7 Februari 2007.

Siyaranamual, J. R., \& Siahaan, H. (1997). Etika, Hak Asasi dan Pewabahan AIDS. Jakarta: Sinar Harapan.

Sontag, S. (1989). Illness as metaphor and AIDS and its metaphors. New York: Doubleday Publishers.

UNAIDS. (1999). From Principle to Practice Greater Involvement of People Living with or Affected by HIV/AIDS (GIPA). Geneva, Switzerland: Joint United Nations Programme on HIV/AIDS (UNAIDS).

Watson, M. S., Lucas, C. F., Hoy, A. M., \& Back, I. N. (2005). Oxford Handbook of Palliative Care. New York: Oxford University Press.

WHO \& ILO. (2007). Post Exposure Prophylaxis to Prevent HIV Infection; Joint WHO/ILO Guidelines on Post-Exposure Prophylaxis (PEP) to Prevent HIV Infection. Geneva, Switzerland: WHO and ILO.

WHO. (1969). Expert Committee On Medical Rehabilitation. Technical Report Series, (419), 1969.

WHO. (2010, July). Priority Interventions. HIV-AIDS Prevention, Treatment And Care In The Health Sector.

WHO. (2011). Global HIV/AIDS response: Epidemic update and health sector progress towards universal access: Progress report. Geneva, Switzerland: WHO.

WHO. (2012). HIV Operational Plan 2012-2013: WHO's Support to Implement the Global Health Sector Strategy on HIV/AIDS. Geneva, Switzerland: WHO

\section{Copyrights}

Copyright for this article is retained by the author(s), with first publication rights granted to the journal.

This is an open-access article distributed under the terms and conditions of the Creative Commons Attribution license (http://creativecommons.org/licenses/by/3.0/). 